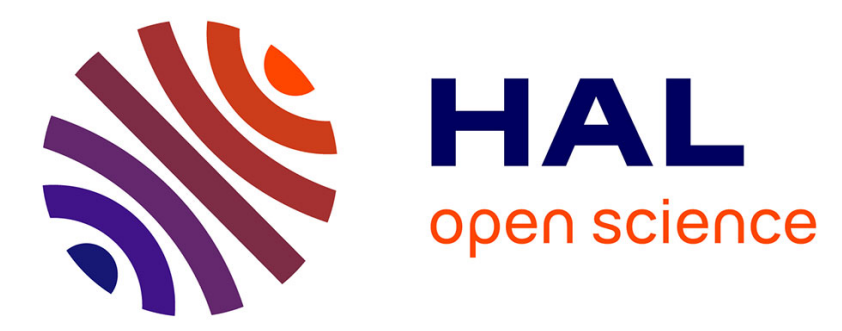

\title{
Regulating migration and asylum in the Maghreb: what inspirations for an accelerated legal development?
}

Delphine Perrin

\section{To cite this version:}

Delphine Perrin. Regulating migration and asylum in the Maghreb: what inspirations for an accelerated legal development?. Cambridge University Press. Migration in the Mediterranean Mechanisms of International Cooperation, F. Ippolito and S. Trevisanut (eds.), pp.192 - 214, 2016, 10.1017/CBO9781316104330.009 . hal-01395111

\section{HAL Id: hal-01395111 \\ https://hal.science/hal-01395111}

Submitted on 10 Nov 2016

HAL is a multi-disciplinary open access archive for the deposit and dissemination of scientific research documents, whether they are published or not. The documents may come from teaching and research institutions in France or abroad, or from public or private research centers.
L'archive ouverte pluridisciplinaire HAL, est destinée au dépôt et à la diffusion de documents scientifiques de niveau recherche, publiés ou non, émanant des établissements d'enseignement et de recherche français ou étrangers, des laboratoires publics ou privés. 
in Migration in the Mediterranean - Mechanisms of International Cooperation, F. Ippolito and S. Trevisanut (eds.), Cambridge University Press, 2016, pp.192-214

\title{
Regulating migration and asylum in the Maghreb: What inspirations for an accelerated legal development?
}

\author{
Delphine Perrin
}

From the emergence of a 'fortress Europe' in the 1990s to the constitution of a 'sentinel Maghreb' in the 2000s, law has accompanied the evolution of migration policies on both sides of the Mediterranean. In the European Union (EU), the harmonisation of immigration and asylum policies has led to the revision of legislations in all the Member States on the basis of common standards and newly created norms. In the Maghreb States ${ }^{1}$, the legal frameworks governing border crossing and migration have been reformed. Those developments in States devoid of any migration policy hitherto and particularly lacking in terms of law-making and -implementing have been largely attributed to the influence of their neighbourhood with the EU. However, the enactment of new laws to control migration 'as a core element of sovereignty' ${ }^{2}$ and national security has also been a global trend since the mid-1990s. ${ }^{3}$ Diversity in the scope, content and implementation of Maghrebian reforms in the 2000s as well as more recent evolutions in the region confirm that legal development, if any, has been the result of a complex and country-specific process in which various and evolving cross-level factors have interacted.

Although Maghreb States had long experience in receiving migrants to various degrees, ${ }^{4}$ they had never considered the necessity to organise or control migrants' stay, which was generally temporary, informal but tolerated. Until the 2000s, migration-related regulations in the Maghreb were particularly dated, short and lacking, and above all not implemented. Perceived as a social reality to ease, migration was not framed, be it to protect migrants or to repress them; and expulsions from time to time was the only 'migration policy' in the region. Mobility was also facilitated by a network of bilateral visa waivers within the Maghreb and across the Maghreb and sub-Saharan Africa. ${ }^{5}$ This laissez-faire has been both legitimised and altered when the Maghreb has been depicted as a transit zone to the EU. The term suggested that Maghreb States were above all a temporary base for migrants and a springboard to the EU for most of them. Migration in the region has hence become a political issue, yet a political issue externally oriented and focused on border control.

Migration situations and policies in the Maghreb have obviously been impacted by evolutions in the EU in the 1990s. The generalisation of visa requirements and other obstacles to regularly enter the EU have altered roads and conditions to reach the continent, and migrants have growingly had to use irregular means and to transit to various countries to attain their goal. In the early 2000s, the EU has developed the external dimension of its asylum and immigration policy aimed at sharing with origin and transit countries the responsibility to control its borders and at containing migrants upstream. To spur the adoption in third countries of regulations and policies likely to meet this objective, it has associated migration to other sectors of cooperation

\footnotetext{
1 The Members of the Arab Maghreb Union (AMU): Mauritania, Morocco, Algeria, Tunisia, Libya.

2 Dauvergne Catherine, 'Irregular Migration, State sovereignty and the Rule of Law' in Research Handbook on International Law and Migration (Cheltenham, UK; Northampton, MA, USA: Edward Elgar, 2014), pp.75-92, 80.

${ }^{3}$ Atak Idil and Crépeau François, 'National Security, terrorism and the Securitization of Migration', Research Handbook on International Law and Migration, (Cheltenham, UK, Northampton, MA, USA: Edward Elgar, 2014), pp. 93-112.

4 For Maghreb countries' migration profiles, see the Migration Policy Centre's website: http://www.migrationpolicycentre.eu/publications/migration-profiles-fact-sheets/

5 Perrin Delphine, 'La circulation des personnes au Maghreb', CARIM AS 2008/46, Robert Schuman Centre for Advanced Studies, San Domenico di Fiesole (FI), European University Institute, 2008, pp.1-17.
} 
with its neighbourhood and adopted regulatory instruments, incentives and capacity tools ${ }^{6}$ oriented to governments. It has also initiated and supported a series of awareness-raising, training and research projects dedicated to or involving civil servants, the civil society and academics. The impact on Maghreb States is not only due to power asymmetry and face-to-face with the EU, accentuated by division among them. It has also to do with historical ties and growing entanglement between individuals, networks and institutions of both sides of the Mediterranean.

Maghreb States initially claimed their rejection to become EU's border guards and to take the responsibility of migrants who were considered as dedicated to the EU. Yet, contributing to border control has progressively turned into a bargaining tool, and singularly with the Member States situated at EU's external borders placed under particular pressure by the Schengen system. ${ }^{8}$ Then, from 2003 on, each of the Maghreb States adopted laws in the domain of migration, something that had not been done since independence or even before. ${ }^{9}$ They also engaged into some bilateral cooperation, exclusively on a north-south vertical basis while south-south horizontal relations remained characterised by mistrust and competition. Developed within a very short period of time and exclusively oriented toward repression, these policy, legal and operational changes have been in part due to the influence of EU normative power. ${ }^{10}$ They are also to be placed within the global context of converging approaches to migration, turned to migrant criminalisation and border securitising. Besides, Maghreb's authoritarian governments have not been very reluctant to join a dominant repressive discourse that could legitimate and reinforce their regime. They have hence followed and participated in the global converging trend, yet diversely, on the basis of their own national specificities.

If the political inspiration of the 2000s reforms appears quite clear, its transcription in legal terms is more puzzling. When States do not know how to legislate, they copy foreign sources and may choose eclectically from several of them. ${ }^{11}$ It has been true in Maghreb States, which have picked some foreign, well-shared legal options to counter irregular migration. They have also produced or maintained some national specific rules inspired by their own political culture and by new political or legal notions that have emerged at the global level. Legal 'development' with its positive connotation is not an appropriate term for the distorted and misimplemented normative production of the past decade in the region.

\footnotetext{
${ }^{6}$ Balzacq Thierry, 'The External Dimension of EU Justice and Home Affairs', CEPS Working document 303 (September 2008), 13. http:// aei.pitt.edu/11659/1/1711.pdf.

${ }^{7}$ For developments on horizontal ties between public administrations in the EU and third countries and the institutionalisation of transgovernmental networks, see Freyburg Tina et al., 'EU Promotion of Democratic Governance in the Neighbourhood', Journal of European Public Policy, 16:6 (2009), 916-934; and Lavenex Sandra and Wichmann Nicole, 'The External Governance of EU Internal Security', Journal of European Integration 31:1 (2009), 83102.

8 The Schengen system indeed assigns to the Member State the responsibility of the migrant/refugee it has enabled entry into the EU.

For an illustration of the diplomatic use of migration pressure, see Libya-Italy (Perrin Delphine 'Fin de régime et migrations en Libye - Les enseignements juridiques d'un pays en feu', L'Année du Maghreb (2011), 285-302; Paoletti Emmanuela and Pastore Ferrucio, 'Sharing the Dirty Job on the Southern Front? Italian-Libyan Relations and their Impact on the European Union', IMI Working Paper, 29 (2010), http://www.imi.ox.ac.uk/pdfs/wp/wp-10-29sharing-the-dirty-job).

${ }^{9}$ In Morocco, regulation dated from the Protectorate era (Dabirs of 15 November 1934, 2 January 1940, 16 May 1941, 17 September 1947, 8 November 1949). In Mauritania (Decree 64-169 of 15/12/1964 related to the immigration regime, Law 65-046 of 23/02/1965 imposing penalties related to immigration), Tunisia (Law 1968-7 of 8/03/ 1968 on foreign nationals, Law 1975-40 of 14/03/1975 on passports and travel) and Algeria (Decree 66-211 of 21/07/1966 on foreign nationals in Algeria), they were adopted in the 1960s. Only Libya adopted a law in the 1980s: Law 6 of 1987 on admission and residency of foreign nationals.

${ }^{10} \mathrm{EU}$ capacity as a foreign policy actor to shape, instil and diffuse rules and values in international affairs (Manners Ian, 'Normative Power Europe: A Contradiction in Terms?', Journal of Common Market Studies, 20:2 (2002), 235-258; See also Tocci Nathalie 'The European Union as a Normative Foreign Policy Actor', CEPS Working document 281(2008), http://aei.pitt.edu/7582/.

${ }^{11}$ Twinning William, 'Diffusion of Law: A Global Perspective', The Journal of Legal Pluralism and Unofficial Law, 49 (2013), 1-45, 18.
} 
Ten years after improvising reforms, Maghreb States are engaged in new migrationrelated legal developments. The multiplicity of influences and the country-specificity of their interrelation in the process of law- and policy-making are currently appearing more clearly, as factors and actors have been renewed and diversified; normative interactions likely to orientate them have proved to be complex and plural. Consensus about migration management has been shown to crack, be it at global, regional or national levels. The human cost of such policies as well as their lack of efficiency to curb irregular migration have led to reactions of transnational civil society, as well as divisions within institutions and among States. Besides, Maghreb societies have been gradually appropriating the migration debate. The development of activist networks, the 2011 uprisings as well as some social and political maturation have been interfering to instigate renewed policies and frameworks around the question of migrant reception and refugee protection. This process is yet evolving on a hesitating and chaotic basis; opposing forces are interrelating in each of those countries. It also unfolds a strong heterogeneity among Maghreb States, diversely prepared for such an enterprise.

Only Morocco and Mauritania are now engaged into drafting comprehensive legal frameworks for immigrants. With Algeria and Tunisia, they have also announced the building of national asylum regimes. Current progress in legal drafting have so far foreshadowed the 'transnational emulation" ${ }^{12}$ of international and mostly EU foreign standards in the forthcoming reforms, which go much further than the picking trend of the previous decade and moves closer to mimicry. The absence of impact of the African legal legacy or of a supposed African approach to migration is noticeable. Rather than quizzing the capacity of Maghrebian and more generally African leaders to build legal and policy alternatives today, this observation leads to transcend a cultural interpretation of legal development. Law-making in the field of migration in the Maghreb is first of all a national issue, which is rooted in a multiplicity of influences and is inspired by various objectives.

\section{Legal picking to counter irregular migration: between followership and improvisation}

Evolution in European asylum and immigration policies in the 1990s has been representative of a global trend pursuant to the end of the Cold War, when political discourses and legal approaches converged into securitising and criminalising migration. Refugee law also experienced a major crisis, Western States sought to avoid receiving any more refugees, either through the creation of alternative status, the development of accelerated procedures or through transfer to a cooperative neighbour. ${ }^{13}$ The more immigration and asylum policies have been closed and restricted mobility, the more migration and refuge seeking have been spreading on an irregular and/or clandestine basis, forming the so-called mixed flows, and the more it has justified repression. The multiplication of formal and informal networks and fora related to migration management has contributed to the diffusion of common political lines and practices. Against this background, the unprecedented normative production related to migration in the Maghreb has been essentially oriented toward repression and rights deprivation.

The regional legal wave started in 2003 with the adoption, in Morocco, of Law 02-03 on the Entry and stay of foreign nationals into the Kingdom of Morocco, on irregular emigration and immigration. It was soon followed by a more limited reform in Tunisia, with Law 2004-06 modifying Law 1975-40 to organize Repression of irregular entry and exit. Both titles purposely associate entry and exit to stigmatise transit migration as the target of repression. Although Algeria initially criticised those reforms in its neighbourhood, it eventually joined the trend with adopting Law 88-11 on the Conditions of entry, stay and movement of foreign nationals in 2008 and reforming its penal code in 2009 (Law 09-01). Libya started to change its immigration law

\footnotetext{
${ }^{12}$ Lambert Helene, 'Introduction: European Refugee Law and Transnational Emulation', in H. Lambert, J. McAdam and M. Fullerton (eds), The Global Reach in European Refugee Law (Cambridge University Press, 2013), pp.1-10.

${ }^{13}$ See Australia's 'Pacific solution' experienced in 2001 with Nauru and Papua-New Guinea.
} 
from 2004 (Law 2) until adopting Law 19 of 2010 to combat irregular migration. Last, Mauritania engaged in a large reform to frame immigration and asylum from 2008, which is still in discussion, and adopted a Law in 2010 to combat the smuggling of migrants. Displaying a readiness to join global and regional combat against crime and irregular migration, the reforms have affected both foreign and national citizens in the Maghreb, by their distorted legal content and their failing implementation.

\section{From targeting transit migration to penalising 'irregular exit'}

Despite a similar repressive orientation, the new legal frameworks are diverse. At the two extremes of the region, Mauritania has opted for mimicry in copying French previous laws ${ }^{14}$ and importing EU norms, whereas Libya has maintained a high degree of specificity. In the 'core Maghreb' (Algeria, Tunisia, Morocco), legal imports have been partial and cohabited with original creation, which has put laws' consistency at stake. Some commonalities seem more inspired by political influences than by law diffusion. ${ }^{15}$

A first commonality of the new laws has been the extension and intensification of sanctions against foreign nationals' irregular entry and stay in the territory. Penal sanctions already existed in the precedent frameworks; they have been considerably raised, in particular in Algeria where the penalty for an irregular stay passed from a fine to a possible jail penalty of six months to two years. Administrative sanctions have also been introduced, such as the prohibition from re-entering the national territory. Mechanisms to contain and detain migrants have been developed, like waiting zones in ports and airports (Morocco, Mauritania) and administrative detention (Morocco, Algeria, Mauritania).

While legal imports can be evoked to this regard, the lack of procedural guarantees and substantial protection to limit and balance extended criminalisation supports the 'picking' interpretation: non-existent in Tunisia and Libya, such guarantees are greatly lacking in Algeria, and those introduced in Morocco have not been implemented. ${ }^{16}$ They are much more developed in the Mauritanian draft law, which has included international standards but has not eventually been adopted. Indeed, it was then considered too lax and removed from the Senate's agenda in 2010 for further discussion. ${ }^{17}$

Foreign migrants have actually been 'managed' as before, that is though expulsions and push-back at border. Yet, these practices have multiplied as well as administrative detention. Without putting an end to informality, the new approaches to migration have turned a number of hitherto tolerated migrants into henceforth irregular migrants. This shift has been more the result of a political change than of the legal reforms. In 2007, Libya submitted regular labour immigration to the requirement of a work contract and authorisation. ${ }^{18}$ However, most aliens working in the informal sector have not been able to be regularised, in the absence of administrative procedure, institution, training and 'culture' to do so. Except in Tunisia, whose 2004 Law was circumscribed to repression, the Maghrebian reforms also allegedly aimed at rationalising migration and modernising its legal framework, in particular through listing conditions for stay permits delivery. Nevertheless, legal access to work permits and thus to regular stay has not been extended in Algeria and Morocco for instance. as most civil servants and judges have been unaware of it, Moroccan Law 02-03 has not been implemented whether as regards its protective provisions (e.g. non expulsion of pregnant women and children) or its

\footnotetext{
${ }^{14}$ Cimade, Prisonniers du désert - Enquêtes sur la situation des migrants à la frontière Mali-Mauritanie, Report (2010), p.28.

15 The following is a comparison of the above-mentioned reforms, including the Mauritanian $2008 \mathrm{draft}$ law although it has not been eventually adopted.

${ }^{16}$ Nadia Khrouz, Conference in Rabat, 'Immigration, social changes and legal changes in the Maghreb', 2 March 2011.

${ }^{17}$ National Strategy for a Better Migration Management, Official Mauritanian Document, October 2010, p.10.

${ }^{18}$ Nevertheless, it is noteworthy that a three month-stay is authorised for job seeking (Perrin, 'Fin de régime et migrations en Libye', p.291).
} 
repressive provisions (pre-existing laws have instead been applied). More generally, the lack of institutional and procedural development needed for law implementation and the absence of awareness-raising in the administration and among migrants have not permitted the implementation of those provisions.

Maghreb States were actually not prepared nor were they willing to address and manage migrants. The political target being the repression of irregular migration dedicated to the EU, reforms were primarily aimed at diffusing a political message to meet regional and global expectations. Repressing and curbing the use of their territory as a transit base to reach Europe was the objective claimed by Maghreb governments when adopting their reforms. Within the terminological proliferation supporting the globally converging approach, 'transit migration' had become a key notion and political issue at regional levels to justify a diffusion and relocation of border control strengthening. It aimed to term a wide range of migration practices in a country, which would supposedly not be the migrant's final destination. Associated to the Maghreb, the presumption of transit has been associated to most aliens, be they entered or have they stayed on the territory legally or illegally, to work or to travel, for a short or longer stay. In Libya for instance, where immigrants have formed a large part of the working population for decades, some of them and singularly the 'sub-Saharans' have been depicted as irregular and potential transit migrants, a governmental discourse easily joined by the population. Yet, most of those sub-Saharans entered Libya regularly, exempted from visas since 1998, and worked there on an informal basis like the majority of aliens. Above all, most of the migrants intercepted at sea on their road to the EU were North-Africans. ${ }^{19}$

Stigmatising foreign nationals, and particularly the most visible among them, that is 'subSaharan migrants', was politically justified. It aimed firstly at meeting Europe's requirements and bargaining the migration pressure on the EU. It also served to deny the reality of migration and a need to frame it. Last, it enabled to reassure North-African citizens, who were constituting the larger part of irregular exit toward the EU but were not officially targeted by their governments. It has thus been a great surprise and disappointment when those citizens, in particular in Morocco, Algeria and Tunisia, have realised that they would be the first victims of those reforms.

As transit migration is defined by an entry into the territory followed by an exit therefrom, Morocco and Algeria have created the offence of 'irregular exit from the territory', that already existed in Tunisia. Unexpectedly for the local populations, this offence has included nationals. The Moroccan law comprises a specific chapter on irregular emigration and immigration', distinct from the chapter on aliens' entry and stay, which equally punishes nationals and foreign nationals with a one- to six-month prison penalty and a fine for an irregular exit. In Tunisia, sanctions have been unchanged: the 1968 Law on foreign nationals already foresees a one-month jail penalty and a fine, while the 1975 Law on national passports punishes citizens with a fifteen-day to six-month jail penalty and a fine. Likewise, Algeria distinguishes nationals from foreign nationals but it also differentiates foreign residents from non-residents, to better deter the latter who are more likely to be in transit. The 2008 law has introduced a penalty - the most severe in the region - for non-resident aliens (six months to two years in prison and a fine), while the 2009 reform of the penal code has included a sanction for both nationals and resident aliens: two to six months in jail and a fine. Although Mauritania has not adopted its draft law which does not include the offence of 'irregular exit' anyway - some aliens have been expelled allegedly for 'illegal emigration" ${ }^{20}$ and others have been detained before their expulsion in 'Guantanamito', a detention centre installed in 2006 in Nouadhibou.

\footnotetext{
19 While arrests in Libya in 2002 and 2003 mainly concerned nationals from North, East and West Africa, two-third of them affected North Africans (Egyptians, Moroccans and to a lesser extent Tunisians and Algerians) in 2005. Libyan official data, Organised Crime and Clandestine Migration from Africa to Europe, United Nations Office on Drug and Crime, July 2006.

${ }^{20}$ Cimade, Prisonniers du desert, p.12.
} 
The objectionable legality of such limitations to mobility has been widely commented upon. ${ }^{21}$ The penalisation of territory exit for both nationals and aliens is a specificity of the 'core Maghreb'. When it is not motivated by national security considerations, very few States, among them China, Cuba and Eritrea, prohibit exit of nationals. Criminalising aliens' exit can be found in other transit countries, which do not include their nationals, notwithstanding power asymmetry with the receiving State. Malaysia for instance condemns with penalties migrants leaving its coasts in an attempt to reach Australia, but Mexico has not introduced a penal offence of irregular emigration. Switzerland bluntly assumes the penalisation of an offence defined on external basis by sanctioning with a one-year prison for the alien who, after exiting the country, irregularly enters a third country. Creation in the Maghreb of an offence of irregular exit applicable to aliens and nationals, which has often been attributed to EU's normative power, is actually the result of Maghrebian regimes familiar with State repression interpreting to the extreme global approaches to migration.

\section{From combating transnational criminality to strengthening State repression}

Beside curbing transit migration, joining the fight against transnational criminality has been another claimed objective of the Maghrebian reforms. Both targets have been addressed in diverse ways in the region and have mainly led to intensification of the repressive pressure on national citizens.

Among the three Palermo Protocols adopted in 2000 to supplement the Convention against Transnational Organised Crime, two have been associated to migration. The Protocol against the Smuggling of Migrants by Land, Sea and Air aims at sanctioning 'the procurement, in order to obtain, directly or indirectly, a financial or other material benefit, of the illegal entry of a person into a State Party of which the person is not a national or a permanent resident' (art.3 a). It has been ratified by the Maghreb States, excluding Morocco. The Protocol to Prevent, Suppress and Punish Trafficking in Persons, especially Women and Children, is not specifically dedicated to migrants. It implies the exploitation of individuals, which can be preceded by border crossing but not necessarily. It has been ratified by all the Maghreb States - Morocco acceding on 25 April 2011. Trafficked persons are considered victims in need of protection and, like smuggled migrants, they shall not be prosecuted for the acts covered by the Protocols.

So far, only Algeria and Mauritania criminalise trafficking per se. Morocco is currently (2014) preparing a law to combat it. Tunisia and Libya do not specifically punish this crime, even if some penal provisions can be used in those countries to repress acts constitutive of trafficking. ${ }^{22}$ In criminalising trafficking together with smuggling and irregular exit in its 2009 reform, Algeria has associated it with migration. In contrast, Mauritania's and Morocco's approaches have been rather based on national issues. Mauritania adopted Law Repressing the Trafficking of Human Beings (Law 025-2003) before ratifying the Palermo Protocol in 2005, within a process aimed at addressing slavery, abolished only in 1981, still widely practised and eventually criminalised by a 2007 law. Morocco has been under pressure for years to respond to the exploitation of national domestic workers in the country. ${ }^{23}$

Sanctioning migrant smuggling has proved to be more ambiguous, being at times confused with the offence of assistance to irregular migration and going beyond the letter and

\footnotetext{
${ }^{21}$ Among others, C. Rodier, "Emigration illégale, une notion à bannir", Libération, 13 June 2006.

For developments on the conventional and customary nature of the right to leave any country, see Chetail Vincent, 'The transnational Movement of Persons under General International Law - Mapping the Customary law Foundations of International Migration Law' in Research Handbook on International Law and Migration (Edward Elgar, 2014) pp.1-71, 9-27.

22 Ben Achour Souhayma, 'Le droit tunisien face à la traite des personnes et au trafic de migrants', CARIM ASN 2011/47 (2011), http:// cadmus.eui.eu/handle/1814/17800, pp.12-20.

${ }^{23}$ Baba Naïma, 'Le Maroc face à la traite transnationale: des éléments de réponse', CARIM ASN 2011/43 (2011), pp. $22-32$.
} 
spirit of the 2000 Protocol. Algeria (2009 reform), Mauritania (Law of 10 February 2010) and less explicitly Libya (Law of 23 January 2010) specifically penalise this crime. Even if those laws differ in defining smuggling and in the sanctions they foresee, they do not depart from the spirit of the Protocol, in particular as they punish the organisation of irregular migration (exit in Algeria; entry, exit and stay in Mauritania; exit and entry in Libya) for profit. The absence of reference to a material or financial profit is nevertheless questionable. In addition, the penalisation of smuggling cohabits in those three countries with the penalisation of and increased sanctions against assistance to irregular migration. Assisting a foreign national's irregular entry and stay was already criminalised in former legislations but the organised and/or collective dimension of the offence, based on networks or public offices were lacking. The latest reforms (Algerian 2008 Law, Mauritanian draft Law, Libyan 2004 Law) have increased sanctions and also added aggravating circumstances such as the number and office of the persons involved. Algeria has also included assistance to exit therein.

While smuggling is defined on the basis of its expected benefit, assistance is loosely described (help, facilitation) and likely to cover a wide range of activities. This implicit inclusion of non-profitable assistance to irregular migration in Algeria, Mauritania and Libya becomes explicit in Tunisia and Morocco. Moroccan 2003 Law and Tunisian 2004 Law punish with fines and prison the facilitation of the irregular entry to or exit from the territory of foreign or national citizens. This 'crime of solidarity', as it has been termed in some EU Member States where it exists, enables to threaten large part of the population likely to help foreign or national migrants for religious, familial or humanitarian reasons. The wide pressure on Maghrebian citizens can also be illustrated by a number of criminal novelties, which mix legal imports such as the marriage of convenience (Algeria 2008 Law, Mauritanian draft) and specificities stemming from a national culture of repression (up to four years in prison for hosting an undocumented migrant and penalisation of the non denouncement of undocumented migrant in Tunisia).

Some case-law and data on arrests during the 2000s show that, unlike political discourses, Maghreb citizens have been the first victims of repression against both irregular migration and smuggling. In Tunisia, judges have tended to favour an extensive interpretation of organised facilitation of irregular migration, which has led to raising penalties and extending convictions to citizens renting a boat or trying to leave the country. ${ }^{24}$ Criminalisation's prevailing impact on nationals has also been observed in Algeria, which announced the arrest of 1,016 Algerians in 2006 and 1,500 in 2007 for clandestine emigration's attempt. ${ }^{25}$ Several condemnations have been sentenced for irregular exit from the territory, as early as 2009, including with the highest penalty, that is six months in prison. ${ }^{26}$ Penalisation being highly unpopular, judges then seemed lenient. During the largest trial of harragas carried out in Ain el-Turck on 13 December 2010, the 109 persons prosecuted were released and fined. ${ }^{27}$ Yet, convictions have since resumed. In Morocco, the Interior Ministry announced in 2004 the arrest of 26,000 'clandestine emigrants', including 17,000 aliens who were expelled at the Algerian border $^{28}$ - a figure which supposed that 9,000 Moroccans were arrested. Tribunals have so far decided on alternative legal basis to Law 02-03. Penalties for irregular exit have been mainly based on the penal code, which already sanctioned a set of acts such as using false documents. Some judges have also applied provisions of dabirs adopted under the protectorate and expressly abrogated by law $02-03 .{ }^{29}$

\footnotetext{
${ }^{24}$ Ben Achour, 'Le droit tunisien', p.12.

25 Official data, 2 August 2008, issued by LADDH http://www.algerieladdh.org/?action=actualite_detail\&actualite_id $=123$.

26 Case law and information available on website:

http://www.carim.org/index.php?callContent $=401$ \&callText $=1112$.

${ }^{27}$ A ministerial circular has also been sent to tribunals to call them for clemency regarding Algerian citizens convicted of irregular exit from the territory.

28 M. Lahlou, L'Economiste, 28 April 2006.

${ }^{29}$ See GADEM report, Le cadre juridique relatif à la condition des étrangers au regard de l'application du pouvoir exécutif et de l'interprétation du juge, 2008, pp.26-35, available here: http://www.gadem-asso.org/Etude-sur-le-cadre-juridique
} 
In 2006 and 2007, a dispute opposed Morocco and Libya about Moroccans detained in Libyan jails for irregular emigration's attempt. ${ }^{30}$ The Algerian League for the Defence of Human Rights (LADDH) denounced in 2008 the imprisonment of thousands of Algerian citizens in Libya and Tunisia for seeking to leave the coasts. ${ }^{31}$ In 2011, families of missing harragas were hoping that Tunisian regime's change would help them get information: the number of Algerians imprisoned in Tunisia for this offence being evaluated at around $300 .{ }^{32}$ The crossed detentions of nationals within the neighbourhood have not facilitated already tense relations between Maghreb States and have accentuated social discontent vis-à-vis Maghreb governments that proved to be unable not only to grant a future to their nationals but also to protect them in the region.

While the introduction of the offence of irregular exit had been claimed as a formal concession to external pressure, the effective implementation of sanctions against national citizens was a surprise in countries where emigration represents a hope and security valve, which assured the stability of failing regimes. The repression and containment of nationals henceforth unable to 'vote with their feet' may have played a role in the social situation that led to the 2011 uprisings. The surprise has been all the more strong in Algeria, given the impressive gap between political discourses in favour of mobility and the African approach to $\mathrm{it}^{33}$ and the government's legal options. ${ }^{34}$ In this country and its neighbours, promises and initiatives for further legal development in the domain of migration and asylum have marked the outset of the 2010s, as a result of various social and political evolutions in each of the Maghreb States as well as in the Mediterranean region.

\section{Shaping a sustainable framework for immigration and refugee reception: between appropriation, mimicry and denial}

In contrast to the previous decade, it has become difficult to present a common impetus and orientation in the forthcoming legal and policy development related to migration in the Maghreb. Some evolution is on the way in the five countries, but along various lines or to different degrees. This growing heterogeneity is in part to be related to the country-specific impact of the 2011 uprisings, which have led to significant social and political evolution in which citizens' and migrants' claims could meet. It is also due to the diversification of influential factors and the greater complexity of their interaction in migration law- and policy-making that have preceded, accompanied and followed those events. Indeed, the mainstream approach to migration in the region has been challenged increasingly from the mid-2000s. As early as 2005, major violations of the human rights of migrants, such as killings at Ceuta and Melilla in 2005, deporting at borders or detention in Nouadhibou, led both to the involvement of large NGOs and to the emergence of local civil society. Connection between NGOs and Maghrebian human rights defenders and opposition to governmental migration policies developed its transnational structuration. Fora gathering militants and academics multiplied in the region and worldwide (Maghreb-Sahel Network on migration, Euro-African Manifest, Social Forum on Migration, etc...) to require alternative policies, at times echoed by intergovernmental agencies, such as the UNDP releasing

\footnotetext{
${ }^{30}$ See various articles in the press in 2006 and 2007 (e.g. Dépêche Panapress, 18 Oct. 2006, Maroc Hebdo, 18 Nov. 2007), statements of AFVIC (Association of Families Victims of Clandestine Immigration), and calming messages on the Moroccan Ministry of Foreign Affairs.

31 Press conference, 3 March 2008.

32 Harraga.net, passim July 2011.

33 Algeria and Libya had competed for leadership in initiating an African approach to migration. Algeria held an expert meeting in 2006 to prepare the Common African Position on Migration and Development adopted by the African Union and Libya hosted the Africa-EU Conference on Migration and Development few months later.

${ }^{34}$ Algeria, which has not had its 'Arab spring', has nevertheless been regularly subject to riots for years.
} 
its 2009 global report on human development focused on migration and calling for 'overcoming barriers. ${ }^{35}$

Border-management practices in the Mediterranean have also been harshly questioned in the aftermath of the 2011 upheavals. The civil society has been supported by political and judicial institutions to enable legal incursions at EU's external borders. The ECHR's Hirsi case ${ }^{36}$ brought a clear condemnation of push-back policy and collective expulsions, be it based on a bilateral treaty, which had been practiced by Italy with Libya since 2004 without any political or legal response. Rescue at sea and compliance with fundamental rights in border control have been at the core of reflections and legal reminders in Europe, ${ }^{37}$ whereas practices at EU's external borders have been denounced by the UN special rapporteur on the human rights of migrants ${ }^{38}$ and even by the European Commission. ${ }^{39}$

The multiplication of voices about migration has enriched and matured the debate in some Maghreb States. Combating irregular migration had been considered as an imported and imposed issue both by governments to justify repression and by the civil society to denounce the externalisation of EU's policy. Humanising and framing the reception of migrants on the territory has become a newly appropriated preoccupation. In echoing citizens' claims for rights and dignity, it has taken on a national political dimension. Yet, these evolutions are not equally shared in the whole Maghreb. Morocco is undeniably the most advanced, being motivated both by a leadership in Africa and joining the club of States respecting the rule of law.

Forthcoming reforms may tend to 'normalise' Maghreb states' immigration and asylum legal frameworks, insofar as they would meet international and EU standards in alien receiving. They are largely based on importing and thus consolidating widely shared norms.

\section{National Issue and Bottom-Up Contributions}

As mentioned above, Maghreb States have never developed any immigration policy aimed to organise the settlement and a fortiori the integration of aliens. Apart from students, most of them have had no regular status for their stay and/or work. This situation has not been limited to the 'sub-Saharans' who have constituted the focus of discourses on irregular and transit migration. ${ }^{40}$ It is part of a widespread disregard for law, documents and formalities in the region. The 2000s reforms have not enabled nor aimed to grant a frame for regular stay, in the absence of accompanying measures that would have been needed for their implementation. Besides, the extent of informality/irregularity has made the vast majority of aliens ineligible for a regular stay. To bridge the gap, Morocco and Mauritania have recently launched unprecedented regularisation processes. These concomitant initiatives inspired by similar previous campaigns in some EU Member States, particularly Spain, Italy and France, are nevertheless rooted in specific national contexts.

\footnotetext{
35 Overcoming Barriers: Human Mobility and Development, Human Development Report 2009, United Nations Development Programme.

${ }^{36}$ Judgement of the Grand Chamber of the European Court of Human Rights on the case of Hirsi Jamaa and Others v. Italy (Application No. 27765/09), 23 February 2012.

${ }^{37}$ E.g. Resolution 1821 (2011) of the Council of Europe's Parliamentary Assembly on tThe interception and rescue at sea of asylum seekers, refugees and irregular migrants'; Regulation 1168/2011/EU of 25 October 2011 requiring Frontex compliance with the Charter of Fundamental Rights; Ombudsman's own-initiative inquiry of 6 March 2012 into the implementation by Frontex of its fundamental rights obligations.

${ }^{38}$ Regional Study: management of the external borders of the European Union and its impact on the buman rights of migrants, A/HRC/23/46, 2013.

39 On February 2014, it required Spain to account for the downing of migrants and the use of rubber bullets to deter arrivals at Ceuta.

${ }^{40}$ In Morocco for instance, European undocumented 'expatriates' have been more numerous than Sub-Saharan 'migrants' but not subject to detention or expulsion (Mehdi Alioua, president of GADEM (Anti-racist Group to support and defend aliens and migrants), Conference in Marseille, LPED, 5 April 2014).
} 
In Mauritania, it is linked to preparing the 'new migration management policy' promised in the framework of the $10^{\text {th }}$ European Development Fund obtained for the period 2008-2012, which comprises the commitment to strengthen migration-management capacity and to revise the legal framework of migration. Drafting law related to the entry and stay of foreign nationals and to asylum in Mauritania had started along the National Strategy on Migration elaborated in 2006. Although this draft makes a short specific reference to nationals from the ECOWAS and UMA Member States, considered as 'privileged immigrants" ${ }^{41}$, it has been largely inspired by previous French law. Work on the draft law has been concomitant with an important reform of the Mauritanian citizenship law (Law 2010-023), which reduced access to citizenship through ius soli and naturalisation and was therefore interpreted as decolonising the citizenship regime. ${ }^{42}$ After citizenship rules had been refined, a census was carried out in 2011 to better distinguish aliens and nationals and prepare the issuance of secured digital identity documents. Tensions associated to the census revealed how national cohesion and migration management are interrelated. Part of the so-called Negro-Mauritanians denounced an attempt to remove their citizenship, and their assimilation to nationals from neighbouring states. The debate about equality between Mauritanian citizens rose in parallel with the issue of the treatment of foreign nationals living in the country. In the meantime, a new National Strategy for Migration Management was defined in 2010, whose implementation started in June 2013. After putting in place forty-five border posts at its southern borders to control entry, ${ }^{43}$ the government issued a circular on 13 May 2012 aiming at regularising aliens residing in the country. Imports from French previous practices and inadequacy with the local context have been again criticised. ${ }^{44}$ Regularisation should not only be paid, but was also based on supporting documents like job contracts or leasehold, which are often difficult to get. Member States of the ECOWAS like Senegal and Gambia responded by closing their borders and threatening to expel Mauritanians, which led the Mauritanian government to drop some conditions for 'privileged immigrants', who have been free to enter the country and benefited from stay facilitations so far.

Evolution in Morocco has been both comparable in terms of content and diverse en terms of normative influences. In both countries, the civil society related to migration and its inclusion into transnational networks started in 2005. In the whole Maghreb, the EU has been inspiring not only to spur repressive policies but also to develop human rights considerations. ${ }^{45}$ This has come from the growing connection between activists from both sides of the Mediterranean, but also from the return of nationals or dual nationals, who have brought with them other ways of thinking. It is in Morocco that the civil society in relation to migration has been the most developed. Unlike its Mauritanian and Algerian counterparts, it has had its 2011 Spring. Then it differs from Tunisian activists by its anteriority. The Moroccan 'Movement of 20 February' 2011 included criticism against EU's migration policy considered as humiliating. ${ }^{46}$ Claims for the rights of citizens comprised the rights of expatriates as well as migrants in the territory. The series of reforms announced in September 2013 after the National Council for Human Rights $(\mathrm{CNDH})$ released a report calling for a new asylum and immigration policy in Morocco have been the result of a combination of factors: a democratisation process

\footnotetext{
41 "Privileged immigrants" are citizens of countries linked with Mauritania by bilateral or regional treaties such as the ECOWAS (Economic Community Of West African States) that Mauritania left in 2000, and UMA.

${ }^{42}$ The forms of ius soli in the previous law were exceptional in the region and inspired by French Law (Perrin Delphine 'Immigration and Citizenship Law in the Maghreb - Turning Aliens into Citizens', EUI Working Paper, RSCAS 2011/40, EUDO Citizenship Observatory (2011), http://eudo-citizenship.eu/docs/RSCAS_2011_40.pdf, p.7).

${ }^{43}$ Document on the National Strategy for a Better Migration Management, October 2010, p.8.

${ }^{44}$ e.g. 'Enquête: carte de séjour en Mauritanie', Rim Web, 7 November 2013 http://rimweb.net/enquete-carte-desejour-en-mauritanie/.

45 Mehdi Alioua, Conference in Marseille.

${ }^{46}$ Chattou Zoubir, 'Printemps arabe et migrations - Evolution des opinions et des politiques au Maroc', MPC Research Report 2012/08 (2012), http://www.migrationpolicycentre.eu/docs/MPC\%20RR\%202012-08.pdf, p.8.
} 
commenced in 2011 with the new Constitution, extending the rights of Moroccans residing abroad and of foreign nationals in the territory; a growing audibility of the civil society and engagement of political parties in human rights; favouring an external image meeting its foreign policy (i.e newly oriented to sub-Saharan Africa, still oriented to the EU, caring for international respectability $\left.{ }^{47}\right)$. The work in progress in 2014 includes regularising a number of foreign nationals living in Morocco; building a national asylum system; drafting three laws to govern asylum, immigration (and replace Law 02-03) and to combat trafficking. While laws are still at the drafting stage, the regularising process started in 2014. Like in Mauritania, criticism has initially been raised against the criteria required to be regularised, ${ }^{48}$ considered as too restrictive and extremely difficult to demonstrate. Nevertheless, the Moroccan authorities proved to be flexible in following the CNDH's recommendation to regularise all female applicants as well as the Syrian claimants. Besides, as a message to the civil society and international partners, the Moroccan immigration bill starts with a list of aliens' rights and liberties. It has been accompanied by elaborating a national strategy for integration, which contains a series of programmes relating to education, housing and employment, among others.

As a decade ago, legal development has suddenly accelerated. After considering for years migration as a passing reality, tolerated and neglected, then as a major security issue, still passing, Maghreb societies are called to think about it in terms of permanence, installation, rights and integration. Challenges are tremendous. Moroccan circular of 9 October 2013 recommending the integration of children of aliens from Sahel and sub-Saharan Africa into the education system had to be followed with awareness-raising measures to avoid widespread discrimination. In Tunisia and Morocco, unprecedented campaigns against racism have brought together claims for the respect of all black people, be they migrants or national citizens ${ }^{49}$ and affected the sensitive and neglected question of diversity in the nation. The political and social instability which has prevailed in Tunisia so far has impeded any real progress in reforming immigration law. The Tunisian civil society nevertheless calls for the reform of 2004 Law and the adoption of a comprehensive framework for immigration and asylum. Strikingly, it is in countries receiving the greatest number of migrants, Algeria and Libya, that reforms are still expected. It somehow confirms that regulating migration has little to do with the extent of the phenomenon but much more with social and political maturation.

\section{Facing the fear for 'Burden transfer' to comply with international standards}

Refugee protection is a related yet distinct issue to migrant reception. It is sensitive in many regards: source of diplomatic tensions, political subversion and legal obligations. It also implies an economic and social capacity the majority of the population does not benefit from. Besides, while the Maghreb States have been closer and closer to refugee crisis since the 1990s (Somalia, Eritrea, Ivory Coast, etc), they have seen in the EU-UNHCR-joined projects aiming at developing their protection capacity an intent to 'transfer the burden' of refugees. Algeria, Morocco, Tunisia and Mauritania adhered to the 1951 Convention on the status of refugees. With Libya, they are also parties to its regional complement, the 1969 OAU Convention governing the Specific Aspects of Refugees in Africa. Although Algeria and Morocco adopted asylum-related regulations (Moroccan Decree $n^{\circ}$ 5-57-1256 and Algerian Decree $n^{\circ}$ 1963-274) and established Refugees and Stateless Persons Bureaus (BRA in Morocco, BAPRA in Algeria), no

\footnotetext{
47 The Moroccan report on the implementation of the International Convention on the protection of All Migrant Workers and Members of their Families was to be examined by the Committee on Migrant Workers the same day as the High Royal Orientations launched a new asylum and immigration policy.

${ }^{48}$ Such as having lived for at least five years in Morocco; having lived together with a Moroccan spouse for at least two years; having been employed for at least two years, etc.

${ }^{49}$ Demonstrations against racism have been organised in 2013 and 2014 in the two countries. In Morocco, a campaign 'don't call me azzi' has been launched and the political party Istiqlal presented a draft law to combat and penalise racism.
} 
national asylum system has been put in place in the whole Maghreb. UNHCR has assumed the main charge of refugee status determination and sought to facilitate access to basic rights, in cooperation with local associations. For years, failures and violations of refugee law have been denounced in the region: non-recognition of UNHCR documents, refoulement, arrests and pushback of asylum-seekers and refugees. ${ }^{50}$ It is only recently that Mauritania, Algeria, Tunisia and Morocco expressed their commitment to develop national asylum systems and have been preparing draft laws. Libya also promised to ratify the 1951 Convention.

Mauritania had preceded the regional movement in including asylum in its 2008 comprehensive draft law. Asylum has then been isolated to constitute a separate draft finalised in 2011. Cooperation with the EU on migration management and UNHCR for the reciprocal repatriation of Senegalese and Mauritanian refugees since 2005 has been highly influential. In the meantime, UNHCR welcomed Algeria's call for assistance in the revision of its asylum regulation in February 2010, an unexpected initiative in a country which has often claimed to be able to deal alone with its refugees - which it reiterated when thousands of Malians were hosted there in 2012.

In the other Maghreb countries, changes linked to the 2011 uprisings have played an important, although diverse, role. In Libya, which has hosted a great number of de facto refugees living for the most part as economic migrants until the war, the commitment was mainly due to the arrival in power of a regime caring for international community's and EU's consideration and breaking with former practices. Legal development and the respect of rules have been at the core of the new government's promises in the domain of migration and asylum. The current chaos is impeding any progress in refugee protection, and the authorities have been accused of refusing cooperation to aid refugees and prevent abuses of asylum-seekers ${ }^{51}$ while they are engaged in EU supported programmes. ${ }^{52}$

The Tunisian commitment to the development of an asylum system is the result of uprisings both at home and in its Libyan neighbour. War in Libya pushed hundreds of thousands of foreign nationals, then Libyans, to flee the country and exposed Tunisia to the greatest refugee crisis in its history. It gave rise to a noticeable collective mobilisation of solidarity among Tunisian citizens who received and supported refugees, which has to be seen together with the emergence of a civil society after fifty years of dictatorship. ${ }^{53}$ It also led to a greater influence of the UNHCR, which dealt with refugee camps. The drafting of an asylum law started in August 2011 and was finalised in December, together with the closure of the Shousha refugee resettlement programme. UNHCR's pressure was above all influential, as it announced the closure of the Shousha camp in June 2013 and the transfer of responsibility of the remaining refugees and asylum seekers to the Tunisian authorities. The latter have been constrained to prepare the delivery of temporary stay permits. ${ }^{54}$ The civil society ${ }^{55}$ has also been engaged, in denouncing the absence of legal framework enabling refugees to move within the territory and to be granted right to stay and work. Its call for temporary protection in Tunisia before a subsequent resettlement, based on mistrust for the government's capacity and will to protect, actually joins the government's position in favour of refugee resettlement. EU's attempt to outsource refugee protection is still feared and criticized, and even more strongly since the adoption in March 2014 of the EU-Tunisia Mobility Partnership, which includes Tunisia's

\footnotetext{
50 See Asylum and Migration in the Maghreb, Country Factsheets, EMHRN 2012, http://www.euromedrights.org/eng/2012/12/21/asylum-and-migration-in-the-maghreb/.

51 Malta today, 27 January 2014.

${ }^{52}$ In January 2014, the EU has announced a $€ 10$ million programme to contribute to the establishment of a 'rightsbased migration management and asylum system in Libya', financed through the European Neighbourhood and Partnership Instrument (ENPI).

${ }^{53}$ Boubakri Hassan 'De l'élan citoyen à la mise en place d'une politique migratoire en Tunisie: l'accueil des réfugiés de Libye en 2011', Migrations Société (Sept-Oct.2012), pp.121-137, 133.

54 They were still not delivered in February 2014 (FTDES statement, 10 February 2014).

${ }^{55}$ In particular the FTDES (Tunisian Forum for Social and Economic Rights) created in 2011.
} 
commitment to develop an asylum system, together with its engagement to negotiate a readmission agreement.

While an EU-Morocco Mobility Partnership was also concluded on 7 June 2013, comprising the same commitments, the Moroccan civil society seeks to go beyond the 'burden transfer' fear ${ }^{56}$ which has so far justified the absence of refugee protection and of any social and political reflection on reception. The development of asylum systems is likely to make Maghreb States be considered 'safe countries ${ }^{57}$, which asylum seekers should be returned to, and where the treatment of asylum requests should be done. Associating readmission negotiations, and possibly agreements, with the development of asylum systems surely contains the promise of discharging EU's protection responsibility on the Maghreb. Morocco nevertheless reopened the BRA in September $2013^{58}$ and started the drafting of an asylum law to be adopted in 2015 .

A striking commonality of the draft laws on asylum is the inclusion of EU-inspired norms and procedures while the input of the OAU Convention is largely ignored. However, here too, options differ from one State to another. The OAU Convention includes a large refugee definition, which covers the 1951 Convention's definition and extends it to victims of generalised violence, considered as a widespread phenomenon in Africa. The Mauritanian and Moroccan ${ }^{59}$ draft laws comprise the subsidiary protection, a status which had been created at EU level to fill the gaps of the 1951 Convention and to protect victims of generalised violence, among others, yet with a possible lower level or shorter length of protection. The Moroccan authorities justify the importation of this status by the necessity to protect victims of torture in accordance with the UN Convention against torture. It should therefore be expected that victims of generalised violence would benefit from the refugee status. However, the Moroccan draft also contains the 'temporary protection' status, again a notion developed at EU level to respond to massive influx of refugees, while the OAU Convention addresses this situation, and foresees a solidarity system to be put in place among State parties in case of overcharge. It is thus predictable that victims of generalised violence will get in Morocco the temporary protection, as it is currently planned for Syrian refugees.

The ignorance of the OAU Convention is even more obvious in the Mauritanian draft, which refers to the latter in defining the refugee, but stipulates that the subsidiary protection for one renewable year - will be delivered to victims of torture as well as victims of generalised violence. Furthermore, the Mauritanian draft includes the 'safe country' notion, which allows the refusal of access to the territory. The 'partial emulation' of EU refugee law, and singularly norms thereof which enable restrictive asylum policies, has been observed in other countries worldwide ${ }^{60}$. More than reducing the scope and contradicting the spirit of African regional law, these legal options are part of what has been denounced in the EU as an externalising policy insofar as they may facilitate a subsequent transfer of responsibility to third countries upstream.

\section{Conclusion}

In Maghreb societies, so far characterised by a low level of legal ordering of human relations, law development in the past two decades has been impressive. However, revision of family law and citizenship law during this period for instance responded to national social needs and political

\footnotetext{
56 Mehdi Alioua, conference in Marseille.

${ }^{57}$ The 'safe third country' notion, together with the 'country of first asylum' notion are included in the EU Directive "Asylum Procedures" (including its revised version which will be implemented from 2015). They allow Member States to reject admissibility and substantial examination of an asylum request if it can be expected that the applicant might benefit from the protection of a third country on the basis of a sufficient link with this country provided s/he can be readmitted, or if $\mathrm{s} /$ he has been granted the refugee status or a sufficient protection in a third country.

${ }^{58}$ Its first mission is to review and validate the files of refugees recognised by UNHCR.

59 As of 28 March 2014.

${ }^{60}$ Lambert Helene, 'Conclusion: Europe's Normative Power in Refugee Law', in H. Lambert, J. McAdam and M. Fullerton (eds), The Global Reach in European Refugee Law (Cambridge University Press 2013), pp.258-267.
} 
claims, and appeared as the result of the meeting between international, regional and national influences, which penetrated existing frameworks. In contrast, migration was previously considered a national issue only as regards the rights of national emigrants abroad. Aliens' mobility and stay were viewed as a 'natural' and passing phenomenon, which was hardly formalised. Shortly, migration has turned from a social reality to ease and laisser-faire into a national political issue to address and frame, a rapid shift which has mainly been spurred from outside. The multifaceted lack of preparation for such a challenge and the diplomatic importance of legislating have led to improvising a first set of normative production focused on enhancing criminalisation of border crossing. Composed of legal picking in foreign laws and national specificities, it has been only partially implemented and mostly to national citizens, while the presence of aliens has still not been framed by applicable norms.

As time does its work, immigration and asylum law-building in the Maghreb has been growingly appropriated as a bottom-up process, which tends to question the top-down interpretation of a model imposed by above (by the EU to the Maghreb and by the State to the society). Local appropriation, however, does not contradict imports and mimicry, all the more as it aims to address issues that have for long been considered as the prerogative of Western destination States. This may in part explain the low level of intake of African norms. Actually, with the exception of the OAU Convention on Refugees, already dated and hardly implemented, there is no such African approach to migration and asylum. Despite recent initiatives on the continent, often supported by or associated with the EU, African States are unlikely to build and suggest common sui generis legal standards on an issue about which they are divided. Although mobility, migration and asylum affect the continent in a specific way, at least in terms of intensity, African leaders do not present any specific policy likely to offer alternatives to widely shared norms. ${ }^{61}$

In countries where reform drafting to frame immigration and protect refugees is the most advanced, that is in Mauritania and Morocco, and to a lesser extent in Tunisia, the influence of EU law or some EU Member States' laws is dominant. However, opposing forces are interfering in current reforming processes as to options in terms of legal imports. The civil society evidently advocates for legislations inspired by the high standards of human rights protection in the EU and ambitiously takes in the integration debate, although it is so contested and challenged in the EU. Draft laws on asylum in contrast import EU norms that have supported restrictive asylum policies and prepared the relocation of refugee protection. As far as immigration is concerned, Maghreb States' recent efforts to develop control of entry at their land borders as well as options in terms of regularisation criteria further confirm the progressive 'normalisation' of immigration policies along Western, and particularly EU, practices. The rapid and intense appropriation of those approaches, on national basis, is challenging in the African context. Adjustments will be needed to enable adequacy with the existing network of bilateral and regional treaties, which have already been often violated, not to mention the necessary search for an adequacy with the social reality of intense mobility across countries of the region.

\footnotetext{
${ }^{61}$ Beyond the scope of this paper are the cases of regional organisations, such as the ECOWAS, which is currently emancipating from its EU model in considering a right of stay for any national of the Member States within the regional space.
} 